\title{
Events of Corrosion Phenomena on Carbon Steel Pipes in Environment of Sea Water and Ammonia Solutions due to the Presence of Sweet Gas
}

\author{
N S Syafei N S ${ }^{1^{*}}$, D Hidayat ${ }^{2}$, Emlliano ${ }^{3}$, L K Men ${ }^{4}$ \\ ${ }^{1-3}$ Electrical Engineering Study Program, FMIPA, Universitas Padjadjaran, \\ Indonesia \\ ${ }^{4}$ Physics study Program, FMIPA, Universitas Padjadjaran, Indonesia. \\ Email : n.suhendi@unpad.ac.id
}

\begin{abstract}
Based on the results of the study that the test sample material using carbon steel pipe plate API 5L-X65 is in chamber. With the research using the three point loading method is the environment of $\mathrm{CO}_{2}$ gas and saturated $\mathrm{H}_{2} \mathrm{~S}$ gas in a solution of $7900 \mathrm{ml}$ of sea water and $100 \mathrm{ml}$ ammonia, the corrosion phenomenon occurs. And the corrosion event that occurs, is stress corrosion cracking transgranular and intergranular based the results of microstructure test results and based the results of polarized microscopy test. The corrosion rate that occurs will increase with the deflection given to the larger test samples for the same exposure time, the corrosion rate that occurs will increase with the stress $\sigma$ given to the test sample getting larger for the same exposure time and inside crack will get deeper with the deflection given to the test sample getting larger for the same exposure time.
\end{abstract}

Keywords: stress corrosion cracking, sweet gas, specimen three-point loading.

\section{Introduction}

Research corrosion rate on carbon steel pipe API 5L-Grade B in the environment of $\mathrm{H}_{2} \mathrm{~S}$ gas $\mathrm{CO}_{2}$ saturated condition in $\mathrm{NaCl}$ solution \{1], the rate of corrosion in the carbon steel pipe 5L-Grade $\mathrm{B}$ in the $\mathrm{H}_{2} \mathrm{~S}$ gas atmosphere and the saturated $\mathrm{CO}_{2}$ conditions in $\mathrm{NaCl}$ solution and acetic acid solution[2], study of crack corrosion cracking due to sweet gas $\left(\mathrm{H}_{2} \mathrm{~S}\right.$ and $\left.\mathrm{CO}_{2}\right)$ on carbon steel pipe API 5L-X65 to corrosion rate in acetic acid solution. ${ }^{[6]}$ Characteristics of the Carbon steel Pipe 5L-X65 API with the Three Point Point $\mathrm{H} 2 \mathrm{~S}$ Gas Temperature Conditions Saturated $\mathrm{CO}_{2}$ in Acetic Acid Solution[8], Hardness Testing and Tensile Test To Determine Hardening Coefficient $n$ An API Material 5L-X65[7]. Analysis of corrosion phenomenon of carbon steel pipe plate API $5 \mathrm{~L}-\mathrm{X} 65$ in a solution of $250 \mathrm{ml}$ of acetic acid and 4750 aquades under conditions of $\mathrm{CO}_{2}$ and $\mathrm{H}_{2} \mathrm{~S}$ gas saturated at room temperature[15]. In the oil and gas industry in the event of stress corrosion cracking will result in fatal, ie pipe rupture that will result in oil and gas production will be stopped.

The corrosion rate on the 5L-X65 API carbon steel pipe with the three point loading method on acetic acid solution filled with $\mathrm{CO}_{2}$ gas and $\mathrm{H}_{2} \mathrm{~S}$ in saturated state[13]. Analysis stress Corrosion Cracking on carbon steel pipe API 5L-X65 in Solution 7900 
$\mathrm{ml}$ of Sea Water and $100 \mathrm{ml}$ of Ammonia filled with $\mathrm{CO}_{2}$ and $\mathrm{H}_{2} \mathrm{~S}$ Gases in Saturated Condition[14].

From the results of research on carbon steel pipe API 5L-X60 that is $17 \mathrm{H} 1 \mathrm{~S}$ will be susceptible to stresscorrosion cracking. And the mechanical properties of the degraded carbon steel pipe API 5L-X60 show higher resistance to corrosion cracking than in carbon steel pipes. Based on observations with fractographic that carbon steel pipe due to the hydrogen embrittlement process will occur stress corrosion cracking, that is caused by hydrogen atoms penetrating into the carbon steel pipe[11] .

High corrosion resistance in stainless steel carbon pipe (super martensite) is commonly used in the oil and gas industry, especially in acid environments. However there are some susceptible to the presence of hydrogen and the corrosion process mechanism will occur in the presence of $\mathrm{H} 2 \mathrm{~S}$ and depending on $\mathrm{pH} \mathrm{H} 2 \mathrm{~S}$ diffuses seeping along the metal structure it will form sulfide metal pores as it reacts on the metal surface, thereby freeing the hydrogen bonded with sulfur which can absorbed and the hydrogen present in the $\mathrm{H} 2 \mathrm{~S}$ solution indirectly causes failure[12].

This results in the loss of early mechanical properties especially resistance to brittle fracture, which is based on engineering calculations at the pipe design stage. At the same time of stress corrosion cracking has been identified as one of the dominant failures in carbon steel pipes in humid environments, which would lead to the breakup of high-pressure gas transmission pipes as well as serious economic losses and disasters.[11] Commercial steel SS-430 undergoes a continuous corrosion process in the $\mathrm{NaCl}$ environment. The corrosion reaction that occurs, is dominated by an anodic reaction. The measured corrosion rate is very small with the tendency to decrease as the concentration of $\mathrm{NaCl}$ solution increases. So it can be concluded that $\mathrm{SS}-430$ has outstanding corrosion resistance in $\mathrm{NaCl}$ environment. The corrosion products occurring on the SS-430 steel surface in the $\mathrm{NaCl}$ environment are predominantly chrome oxide and iron oxide. [4]

Based on the research that has been done, it can be seen that the effect of temperature on the protective properties of poly (TMSPMA) material on the surface of carbon steel by Electrochemical Impedance Spectroscopy (EIS) method in some temperature variations, $25^{\circ} \mathrm{C}, 45^{\circ} \mathrm{C}, 60^{\circ} \mathrm{C}$, and $75^{\circ} \mathrm{C}$. From the results of fittings made to the EIS measurement results obtained information that there is a decrease in the impedance value is often the temperature rise which shows that the resistance of corrosion protection material in critical condition to protect the carbon steel decreases. [5]

The corrosion occurs is the stress corrosion cracking transgranular and the stress corrosion crackin intergranular due to the sweet gas ( $\mathrm{CO} 2$ and $\mathrm{H} 2 \mathrm{~S}$ gas) based on figure 7 and ammonia solution which is an element of ammonia anhydrous condensate. Crack deepness deeper with equal exposure time and variation stress $\sigma$ based on figure 8. [15] Based on the experimental results it is shown that the dominant corrosion product formed is $\mathrm{FeS}$ and the corrosion resistance of tense crack increases with increasing workload, dissolved $\mathrm{H} 2 \mathrm{~S}$ concentration, and time of combustion.

\section{Experimental Section Tools and Materials}

Tools and materials used in this research is a SEM-EDS,_Optical Microscope, polarized microscope. The materials used in this research is the chamber, API 5L-X65 carbon steel plate, acetic acid $\left(\mathrm{CH}_{3} \mathrm{COOH}\right)$, ammonia solution, aquadest, $\mathrm{H}_{2} \mathrm{~S}$ gas and $\mathrm{CO}_{2}$ ga . 


\section{Procedure}

To make a house a corrosion test sample is required a sheet of steel in the form of a plate or flat extruded section with a rectangular cross section. In addition it can also be used cast iron or iron in the form of a beam as shown in Figure 1. The material to be tested is thinly sliced and then bent at both ends to obtain a voltage, and the magnitude of the voltage can be adjusted by providing a deflection through a screw-driven thread as shown in FIG. 1b. And this research uses 5L-X65 API carbon steel plate with length $12.5 \mathrm{~cm}$, width $2 \mathrm{~cm}$ and thickness $2 \mathrm{~mm}$ stored in holder specimen three dot loading as shown (1.a) inserted into chamber room of corrosion test as much as 3 sample test corrosion with deflection variation as shown in figure (1.c) and image (1.d) is a 5L-X65 API test plate ${ }^{[3]}$.
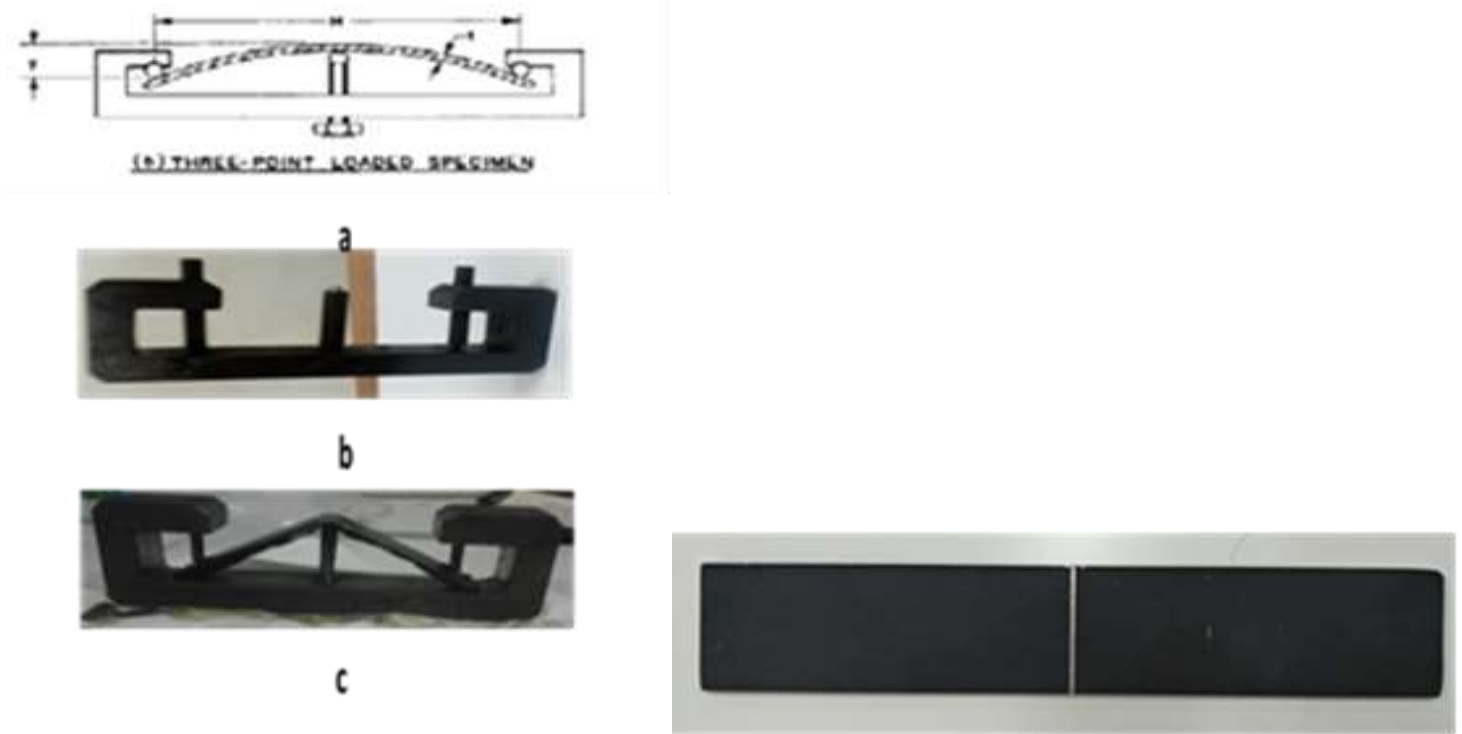

d. Samples of 5L-X6 API test specimens.

Figure 1. Holder shape and mounting of test specimen.

Research carried out that the carbon steel plate of API 5L-X65 is stored in the holder and then inserted into chamber chamber containing $4900 \mathrm{ml}$ sea water and $100 \mathrm{ml}$ ammonia as shown in Figure 2. The population of the corrosion test samples each time variation consists of three carbon API 5L API -X65 with three deflection variations, whereas the weight before and after the corrosion test was weighed.
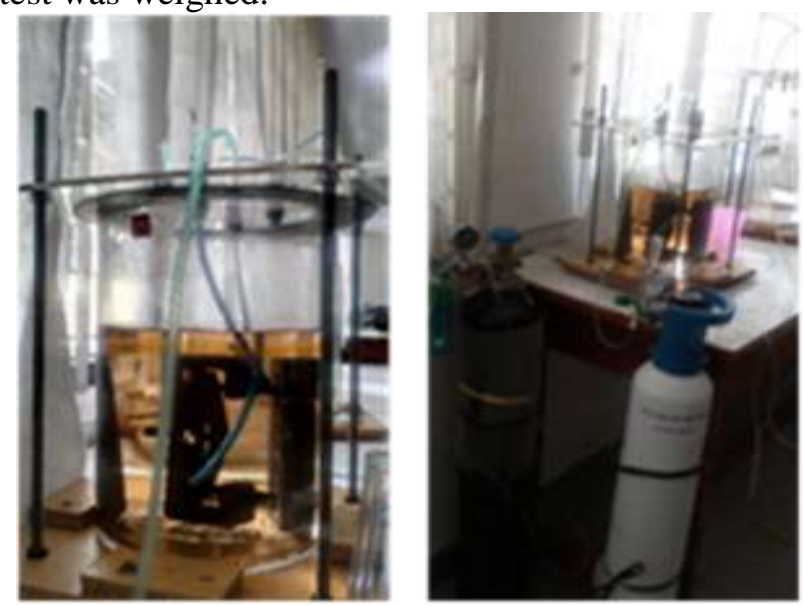

Figure 2. Chamber corrosion test.

88 IEKSAKTA: Berkala IImiah Bidang MIPA 
The tensile test is a mechanical stress-strain test that aims to determine the strength of the material to the tensile force as shown in figure 3. In the test that the test material is pulled to break and usually the focus is the maximum capability of the material in withstanding the tensile load, and the ability / strength This maximum pull is generally called "Ultimate Tensile Strength (UTS)". The long change in the curve is called the technical strain (ceng), which is defined as the change in length occurring due to a static change $(\Delta \mathrm{L})$ to the initial bar length (L0). The stress generated in this process is called the engineering

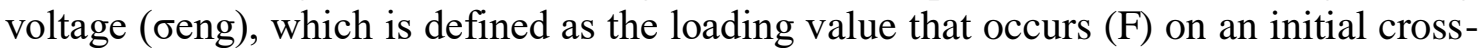
section (A0). The normal stresses due to static press charges can be determined based on the following equation:

$\sigma=\mathrm{F} / \mathrm{Ao}$

with:

$\sigma=$ Normal stress due to static tensile load $(\mathrm{N} / \mathrm{mm} 2)$.

$\mathrm{F}=$ Tensile load $(\mathrm{N})$.

Ao $=$ Area of initial specimen cross section $(\mathrm{mm} 2)$ as shown in Figure 3.
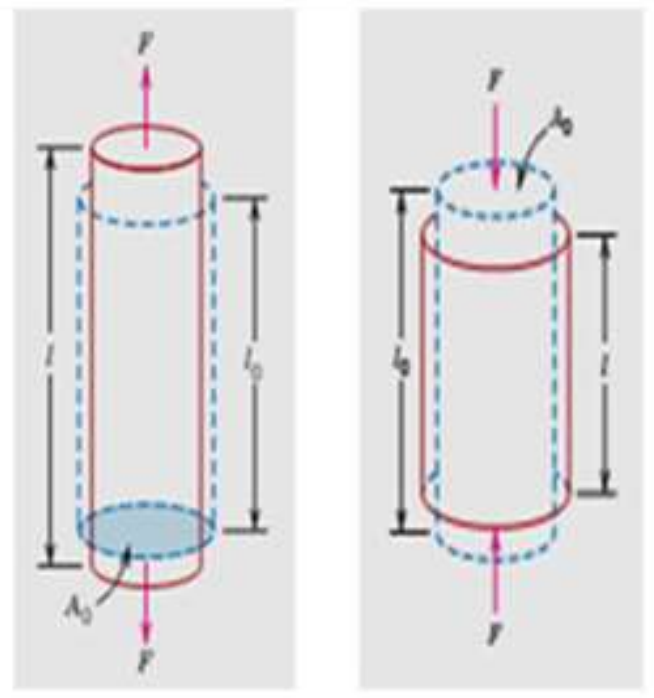

Figure 3. Basic principles of stress / stress (Callister, D. William 2007).

The strain due to the static tensile load can be determined by the following equation:

$\varepsilon=\Delta \mathrm{L} / \mathrm{L}$

with:

$\Delta \mathrm{L}=\mathrm{L}-\mathrm{L} 0, \varepsilon=$ Strain due to static tensile load.

$\mathrm{L}=$ Change of length of specimen due to tensile load $(\mathrm{mm})$.

Lo $=$ The length of the initial specimen $(\mathrm{mm})$.

Flat-shaped specimens have dimensions of width, length, and thickness of specimens usually determined by the product of the material used. The specimen holder in both ends of the specimen is bent / pressed with the screw (fitted with the ball), the support is in the middle of the plane. The dimensions of the specimens used can be modified according to 
the specific needs (materials used), but their proportions are estimated proportionately. Calculation of elastic stress as in the following equation:

$$
\sigma=6 \mathrm{E} \mathrm{t} \mathrm{y} / \mathrm{H} 2
$$

with:

$\sigma=$ maximum tensile stress $(\mathrm{N} / \mathrm{m} 2)$.

$\mathrm{E}=$ modulus of elasticity $(\mathrm{N} / \mathrm{m} 2)$.

$\mathrm{t}=$ specimen thickness $(\mathrm{mm})$.

$\mathrm{y}=$ maximum deflection $(\mathrm{mm})$.

$\mathrm{H}=$ distance between external buffer ( $\mathrm{mm}$ ) and small deflection (y / H less than 0.1$)$ as shown in Figure 3. Flat chip specimens with 25-51 mm (1-2 inches), 127-254 mm length ( 5 - 10 inches) and the thickness of the specimen is usually determined the product of the material used as shown in figure 1.

\section{Results and Discussion}

The data obtained based on the weight before and after the corrosion test was obtained to calculate the corrosion rate, and the test samples were then tested using microstructures and polarized microscope will be seen that the carbon steel plate image occurred corrosion and crack length. This research needs to be developed by using ultrasonic method to find out crack length that is based on reflection of wave that concerning surface of carbon steel plate. And the 5L-X65 API carbon steel plate in the chamber corrosion test chamber is loaded with saturated $\mathrm{CO} 2$ gas, and filled $\mathrm{H} 2 \mathrm{~S}$ gas for 10 minutes every two days as shown in table data 1.

Table 1. Corrosion Rate of Strained and Time Variations in Seeds $4700 \mathrm{ml}, 100 \mathrm{ml}$ Ammonia with $\mathrm{H}_{2} \mathrm{~S}$ and $\mathrm{CO}_{2}$ Saturated At Room Temperature.

\begin{tabular}{|c|c|c|c|c|c|c|c|c|c|c|c|}
\hline No. & $\begin{array}{c}\text { Minitial }_{\text {(gr) }} \\
\text { (I) }\end{array}$ & $M_{\text {final }}(g r)$ & $\begin{array}{c}\text { PH } \\
\text { initial }\end{array}$ & $\begin{array}{c}\text { PH } \\
\text { final }\end{array}$ & $\begin{array}{c}\text { Length } \\
\text { (cm) }\end{array}$ & $\begin{array}{l}\text { Width } \\
\text { (cm) }\end{array}$ & $\begin{array}{c}\text { Thichness } \\
\text { (cm) }\end{array}$ & $\begin{array}{l}\text { Deflection } \\
\text { (y) } \mathrm{cm}\end{array}$ & $\begin{array}{c}\text { Inside } \\
\text { Crack } \\
\text { initial } \\
(\mathrm{cm})\end{array}$ & $\begin{array}{c}\text { Time } \\
\text { Exposure } \\
\text { (hours) }\end{array}$ & $\begin{array}{c}\text { Corrosion rate } \\
\quad(\text { mmpy })\end{array}$ \\
\hline A-1 & 52.99 & 52.96 & 14 & 10 & 13.1 & 2.42 & 2.4 & 0.5 & 0.02 & 336 & 0.031388956 \\
\hline A-2 & 53.73 & 53.53 & 14 & 10 & 13.1 & 2.42 & 2.4 & 1 & 0.02 & 336 & 0.209259709 \\
\hline A-3 & 53.18 & 52.69 & 14 & 10 & 13.1 & 2.42 & 2.4 & 1.5 & 0.02 & 336 & 0.512686287 \\
\hline B-1 & 53.21 & 52.76 & 14 & 9 & 13.1 & 2.42 & 2.4 & 0.5 & 0.02 & 672 & 0.235417172 \\
\hline B-2 & 53.29 & 52.65 & 14 & 9 & 13.1 & 2.42 & 2.4 & 1 & 0.02 & 672 & 0.334815534 \\
\hline B-3 & 53.96 & 52.76 & 14 & 9 & 13.1 & 2.42 & 2.4 & 1.5 & 0.02 & 672 & 0.627779127 \\
\hline C-1 & 53.33 & 52.95 & 14 & 9 & 13.1 & 2.42 & 2.4 & 0.5 & 0.02 & 1008 & 0.132531149 \\
\hline $\mathrm{C}-2$ & 53.13 & 52.7 & 14 & 9 & 13.1 & 2.42 & 2.4 & 1 & 0.02 & 1008 & 0.149969458 \\
\hline C-3 & 53.26 & 52.63 & 14 & 9 & 13.1 & 2.42 & 2.4 & 1.5 & 0.02 & 1008 & 0.219722694 \\
\hline
\end{tabular}

90 IEKSAKTA: Berkala II miah Bidang MIPA 


\begin{tabular}{llllllllllll} 
D-1 & 53.35 & 53.21 & 14 & 9 & 13.1 & 2.42 & 2.4 & 1.5 & 0.02 & 1344 & 0.036620449 \\
D-2 & 53.07 & 52.5 & 14 & 9 & 13.1 & 2.42 & 2.4 & 1 & 0.02 & 1344 & 0.149097543 \\
D-3 & 53.84 & 52.66 & 14 & 9 & 13.1 & 2.42 & 2.4 & 0.5 & 0.02 & 1344 & 0.308658071 \\
\hline
\end{tabular}

The data in table 2 that the magnitude of the strain of each carbon steel sample test sample (figure 1.c with different deflection) is inserted in the chamber as shown in figure 2, and the results of the study based on the variation of time and deflection variation are obtained as in table 1. Based on the data in table 1 that the corrosion rate to the variation of exposure time of the test sample with the same deflection, then obtained the corrosion rate as shown in figure 3 is like a parabola. And the corrosion rate to the variation of stress $\sigma$ at the same exposure time is obtained as in figure 4 , ie the greater the stress $\sigma$ given the greater the corrosion rate for the same time exposure.

Table 2. Table of calculation stress based on equation 3 .

\begin{tabular}{ccccccc}
\hline $\mathbf{N}$ No & $\mathbf{E}\left(\mathbf{N} / \mathbf{m}^{2}\right)$ & $\mathbf{t}(\mathbf{m})$ & $\mathbf{y}(\mathbf{m})$ & $\mathbf{H}(\mathbf{m})$ & $\mathbf{H}^{2}\left(\mathbf{m}^{2}\right)$ & $\boldsymbol{\sigma}\left(\mathbf{N} / \mathbf{m}^{2}\right)$ \\
\hline 1 & $2.05 \mathrm{E}+11$ & 0.0022 & 0.005 & 0.0946 & 0.008949 & $1.51 \mathrm{E}+09$ \\
2 & $2.05 \mathrm{E}+11$ & 0.0022 & 0.01 & 0.0946 & 0.008949 & $3.02 \mathrm{E}+09$ \\
3 & $2.05 \mathrm{E}+11$ & 0.0022 & 0.015 & 0.0946 & 0.008949 & $4.54 \mathrm{E}+09$ \\
\hline
\end{tabular}

Table 3. Table of calculation stress and Corrosion Rate (mmpy).

\begin{tabular}{cccc}
\hline No. & $\begin{array}{c}\text { Stress } \\
\left(\mathbf{N} / \mathbf{m}^{\wedge} \mathbf{2}\right)\end{array}$ & $\begin{array}{c}\text { Corrosion rate } \\
(\mathbf{m m p y})\end{array}$ \\
\cline { 3 - 4 } 1 & 1511873740 & 0.031388956 \\
2 & 3023747480 & 0.209259709 \\
3 & 4535621220 & 0.512686287 \\
1 & 1511873740 & 0.235417172 \\
2 & 3023747480 & 0.334815534 \\
3 & 4535621220 & 0.627779127 \\
1 & 1511873740 & 0.132531149 \\
2 & 3023747480 & 0.149969458 \\
3 & 4535621220 & 0.219722694 \\
1 & 1511873740 & 0.036620449 \\
2 & 3023747480 & 0.149097543 \\
3 & 4535621220 & 0.308658071 \\
\hline
\end{tabular}

Table 4. Data on exposure time and depth of crack.

$$
\begin{array}{|c|c|c|}
\text { Time exposure } & \begin{array}{c}
\text { Depth Crack } \\
(\mathbf{j a m})
\end{array} & (\boldsymbol{\mu m})
\end{array}
$$




\begin{tabular}{|c|c|c|}
\hline 1 & 336 & 62.36 \\
\hline 2 & 672 & 65.32 \\
\hline 3 & 1008 & 66.98 \\
\hline 4 & 1344 & 67.75 \\
\hline 1 & 336 & 69.93 \\
\hline 2 & 672 & 76.76 \\
\hline 3 & 1008 & 78.94 \\
\hline 4 & 1344 & 79.89 \\
\hline 1 & 336 & 85.06 \\
\hline 2 & 672 & 89.86 \\
\hline 3 & 1008 & 90.79 \\
\hline 4 & 1344 & 116.99 \\
\hline
\end{tabular}

Based on table 1 and figure 3, the corrosion rate at the same exposure time will increase as the deflection is given to the test sample, ie the corrosion rate is $\mathbf{y}=\mathbf{0 . 2 5 1 1} \mathbf{x}^{\mathbf{2}}-\mathbf{0 . 0 2 0 9 x}$ $\mathbf{- 0 . 0 2 0 9}$ for exposure time 336 hours, $\mathbf{y}=\mathbf{0 . 3 8 7 1} \mathbf{x}^{2} \mathbf{- 0 . 3 8 1 9} x+\mathbf{0 . 3 2 9 6}$ for exposure time 672 hours, $\mathbf{y}=\mathbf{0 . 1 0 4 6} \mathbf{x}^{2} \mathbf{- 0 . 1 2 2 1} \mathbf{x}+\mathbf{0 . 1 6 7 4}$ for exposure time 1008 hours and $\mathbf{y}=\mathbf{0 . 0 9 4 2} \mathbf{x}^{2}+$ $\mathbf{0 . 0 8 3 7} \mathbf{x}-\mathbf{0 . 0 2 8 8}$ for exposure time 1344 hours.
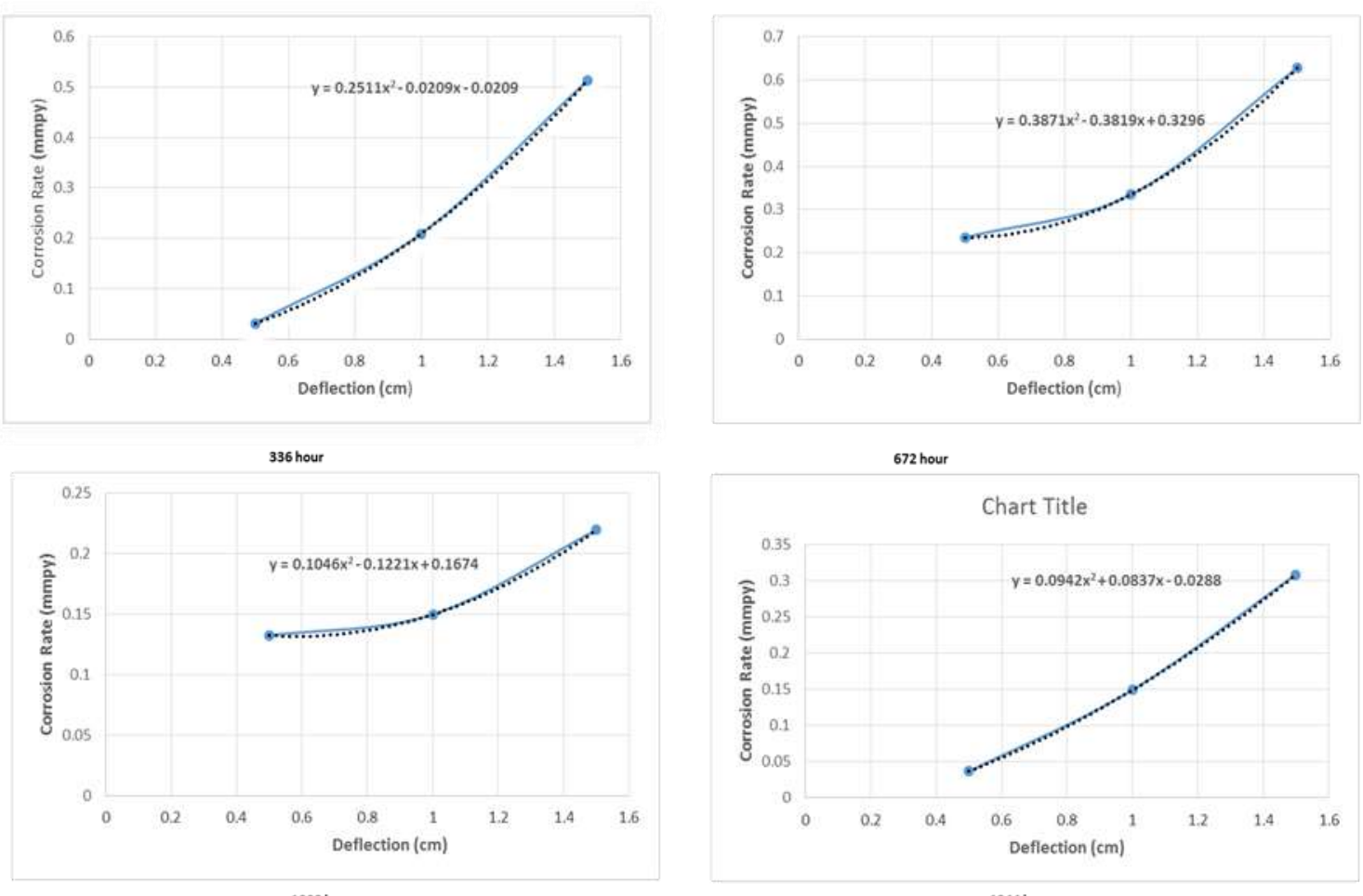

Figure 3. Graph of corrosion rate against deflection variation at the same time exposure. 

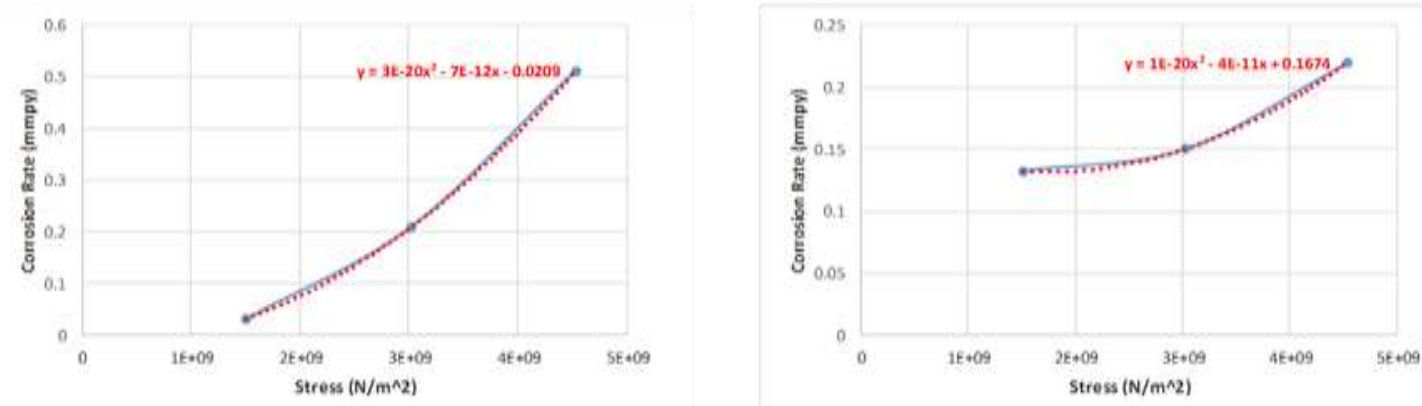

336 hour
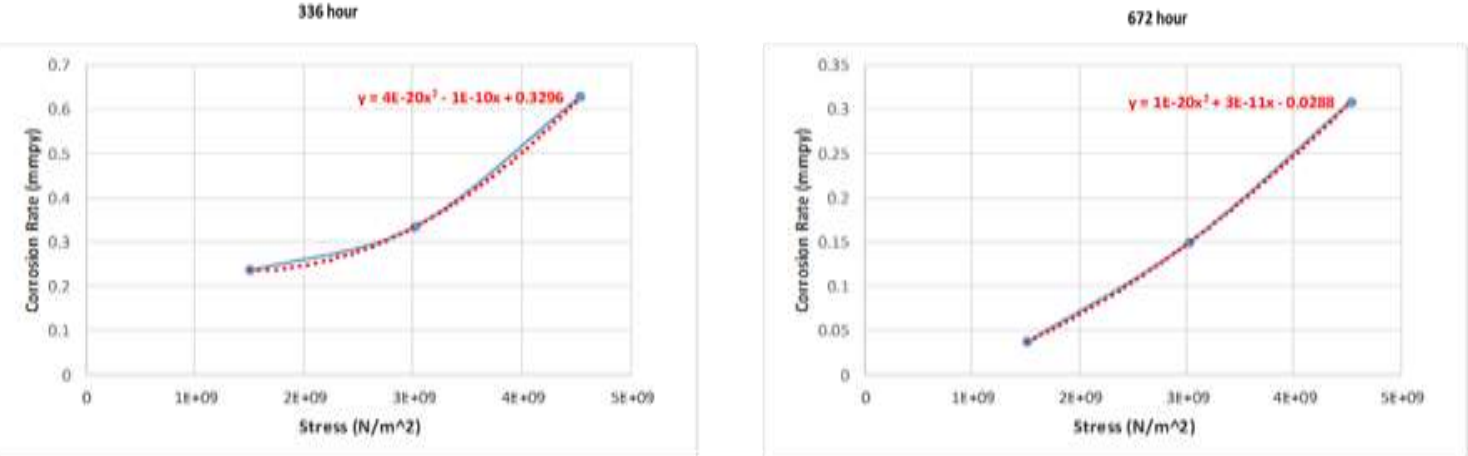

1008 hour

1344 hour

Figure 4. Graph of Corrosion Rate on the variation of stress $\sigma$ with the same time exposure.

Based on table 4 that the depth crack will increase in time as the exposure time is given to the test sample as shown in figure 5, and based on result microstructure shown as in figure 8 with the depth crack $\mathbf{y}=\mathbf{- 5 E}-\mathbf{0 6} \mathbf{x}^{2}+\mathbf{0 . 0 1 3 5} \mathbf{x}+\mathbf{5 8 . 4 0 7}$ for $0.5 \mathrm{~cm}$ deflection, $\mathbf{y}$ $=\mathbf{- 1 E}-\mathbf{0 5} \mathrm{x}^{2}+\mathbf{0 . 0 3 1 4}+\mathbf{6 1 . 0 1 5}$ for deflection $1.0 \mathrm{~cm}$ and $\mathbf{y}=\mathbf{5 E}-\mathbf{0 . 5} \mathbf{x}^{2}-\mathbf{0 . 0 5 0 8 x}+$ 98.245 for deflection $1.5 \mathrm{~cm}$.

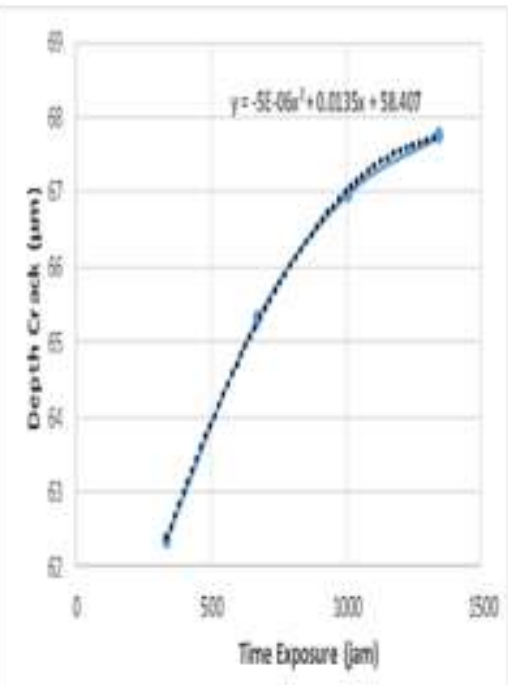

Celuton 05 ism

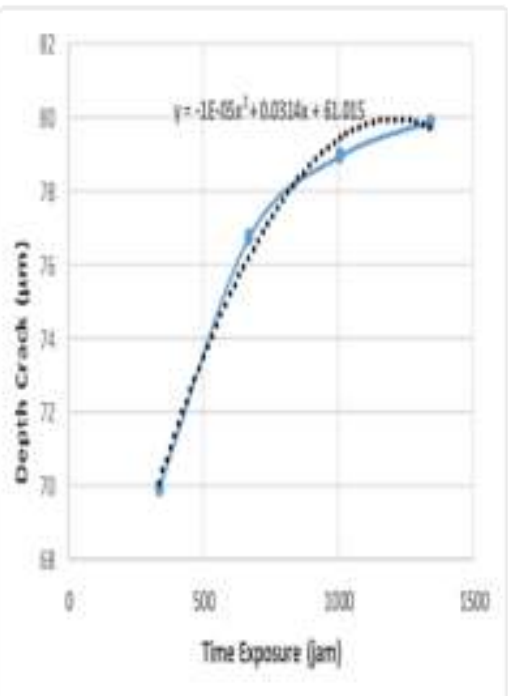

Defesion $10 \mathrm{en}$

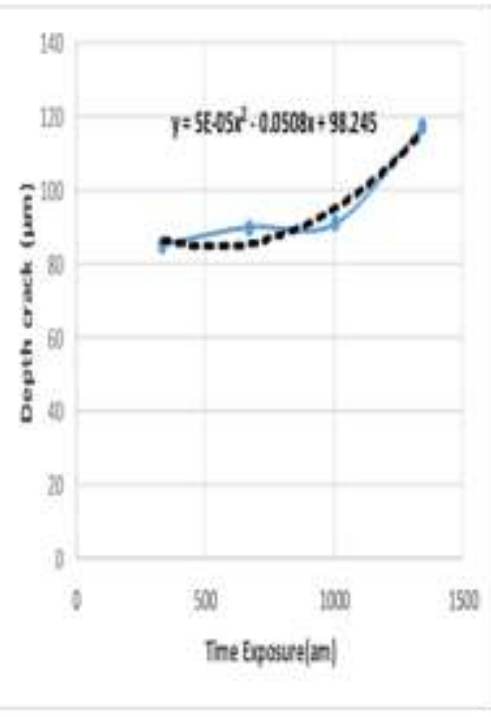

Befution $15 \mathrm{~s}$

Figure 5. Depth Crack to exposure time with the same deflection.

93 IEKSAKTA: Berkala IImiah Bidang MIPA 
Based on the result of microstructure as shown in figure 6 that the uhi sample which is in the solution of $7900 \mathrm{ml}$ sea water and $100 \mathrm{ml}$ ammonia after filled $\mathrm{H}_{2} \mathrm{~S}$ gas and $\mathrm{CO}_{2}$ gas happened corrosion phenomenon, ie stress corrosion cracking of transgranular and stress crack corrosion of intergranular. And based on the results of polarized microscope as in figure 7 there is event a stress corrosion cracking by comparing the results of the microstructure for the same sample.
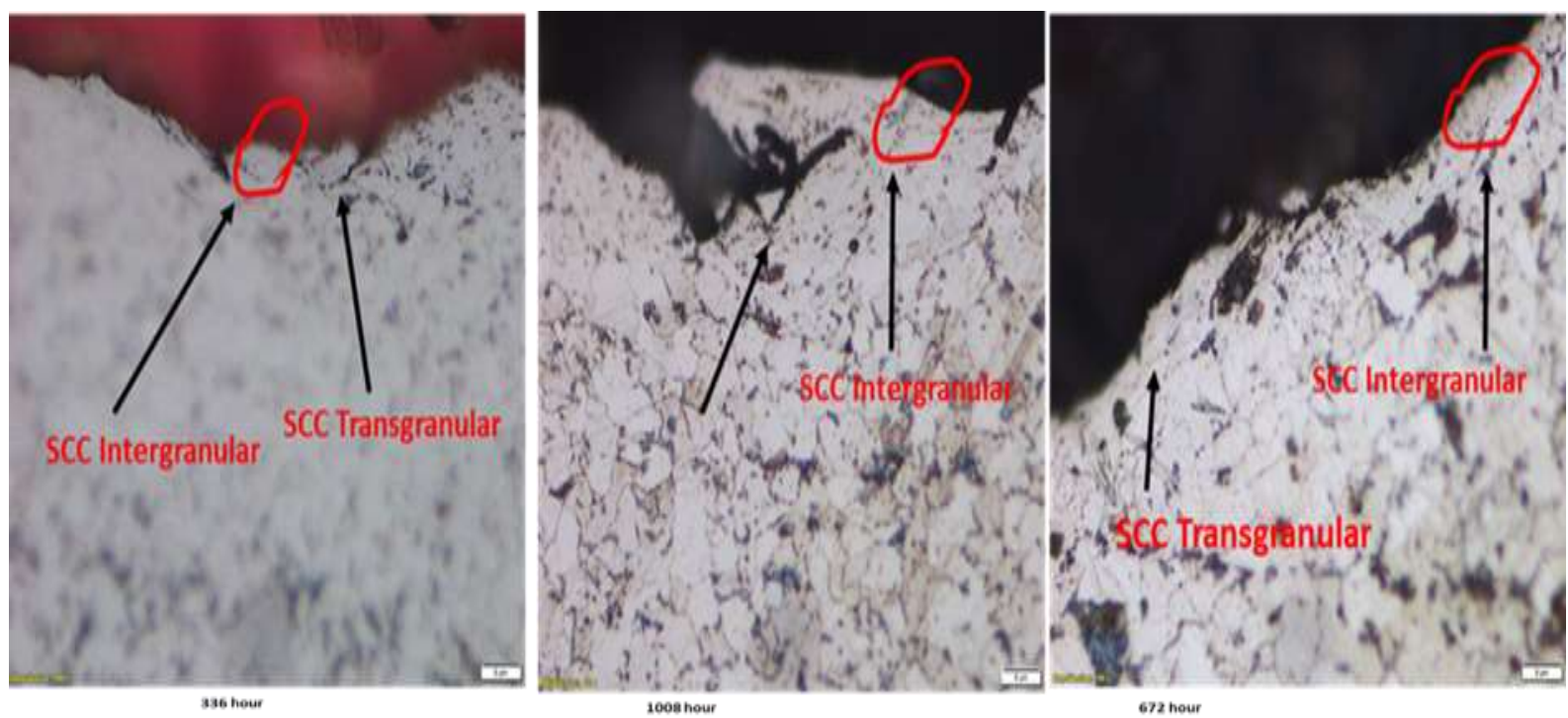

Figure 6. Results of microstructure.

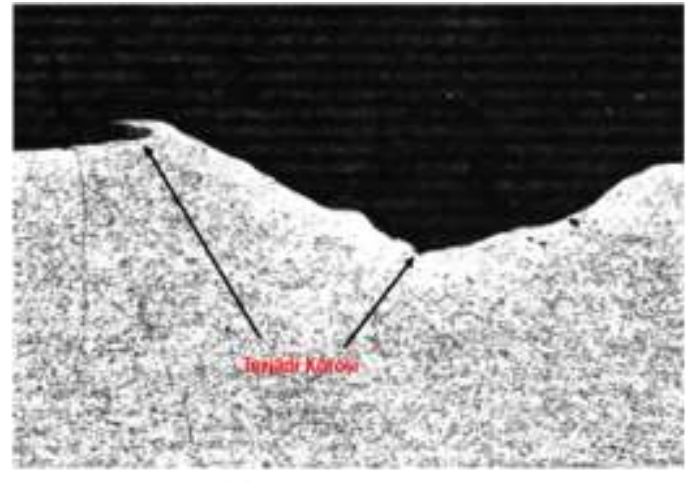

672 hour

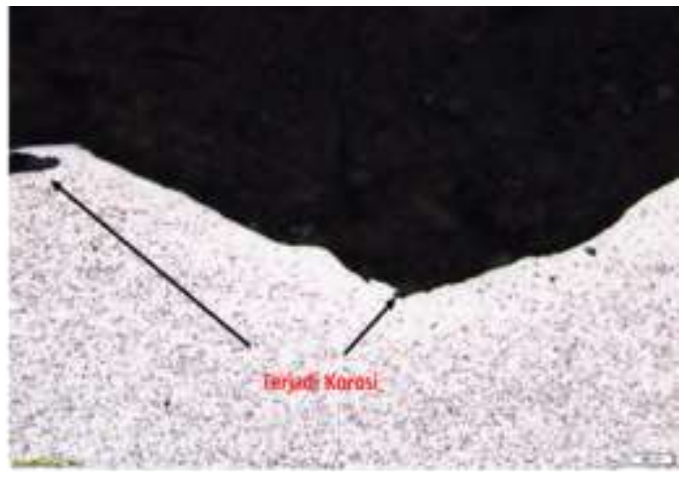

1008 hour

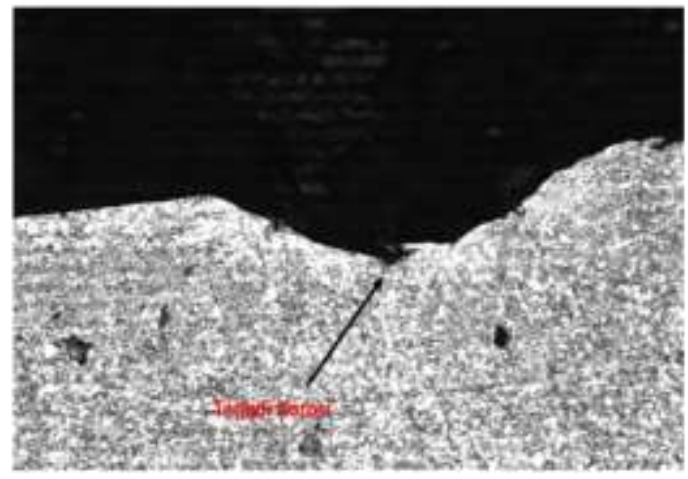

Microscope polarization

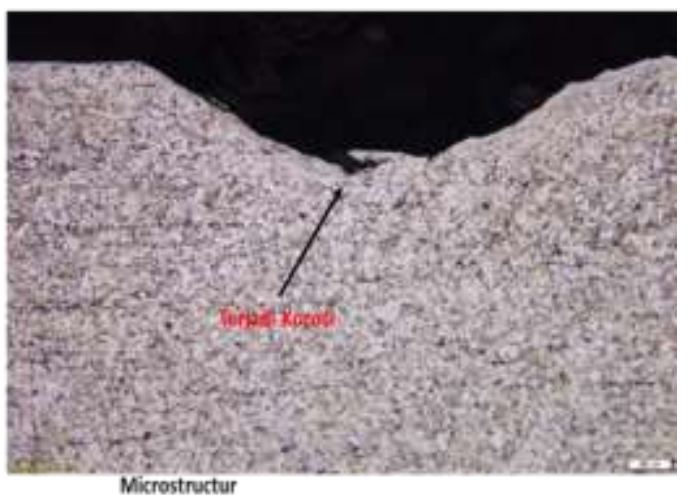

Figure 7. Results of microstructures and polarized microscopy results for the same test sample.

94 IEKSAKTA: Berkala IImiah Bidang MIPA 


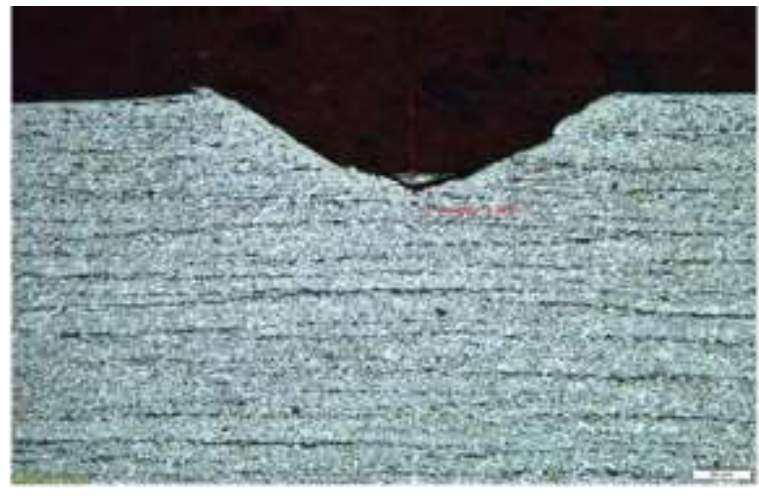

Depth Crack 116,99 um

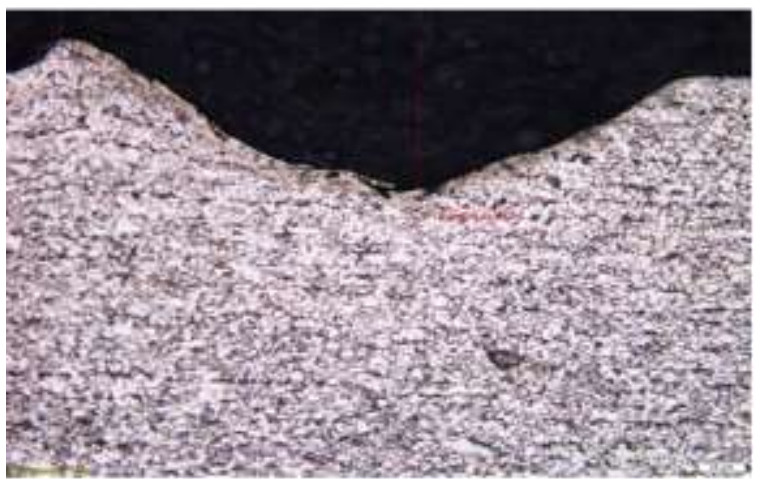

Depth Crack $89,86 \mu \mathrm{m}$

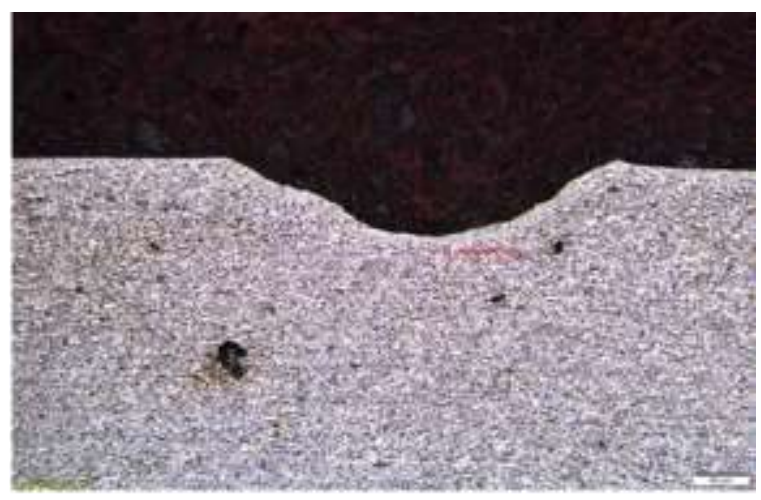

Depth Crack $90,79 \mu \mathrm{m}$

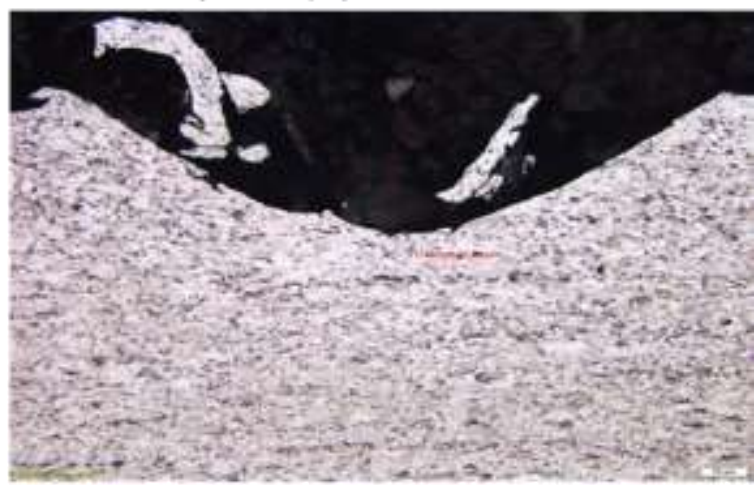

Depth Crack 85,06 um

Figure 8. Depth crack based on microstructure results.
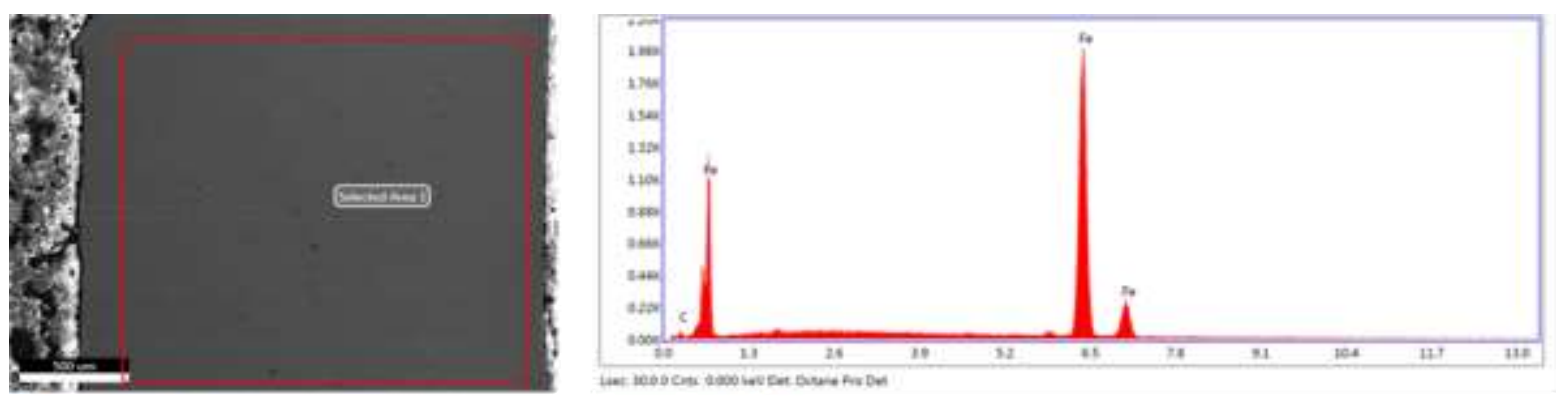

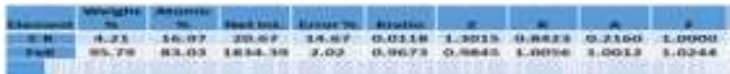
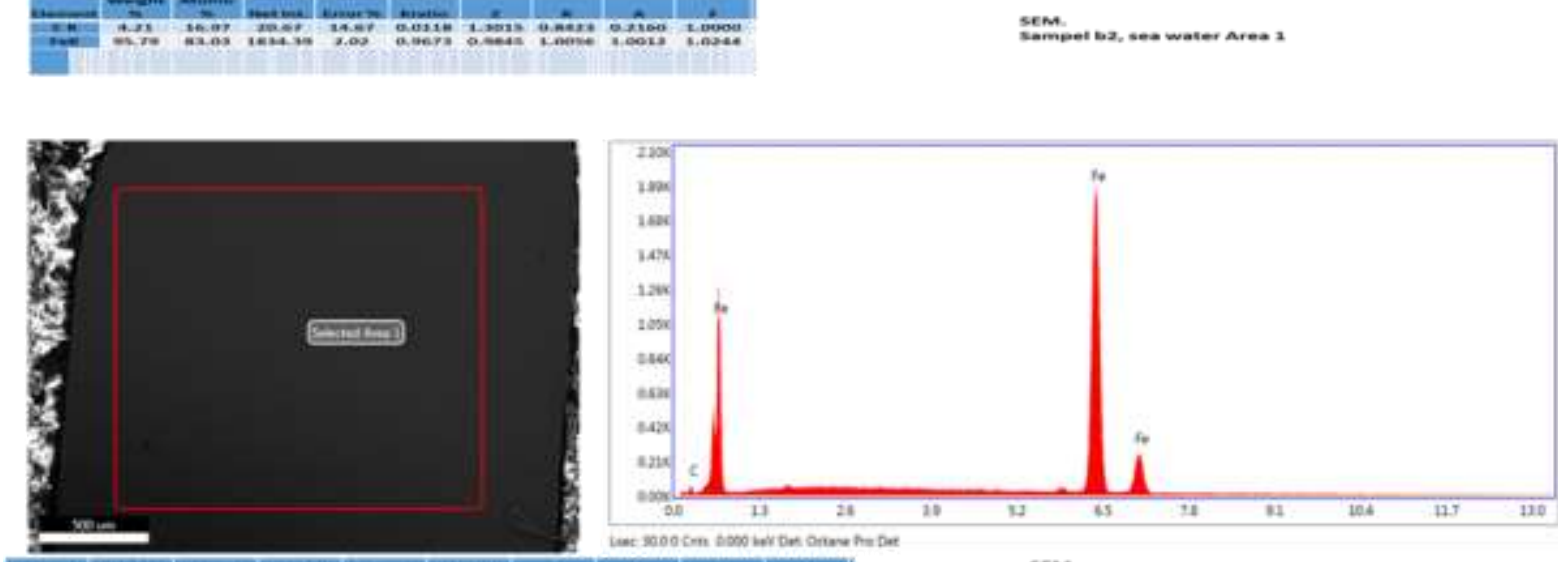

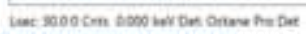

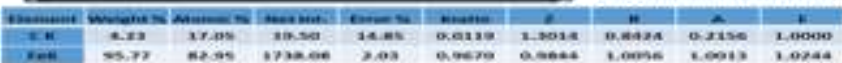

Sempel ca, sea water areas 1

Figure 9. Result SEM-EDS for test sample b2 and c3 test sample.

95 IEKSAKTA: Berkala IImiah Bidang MIPA 

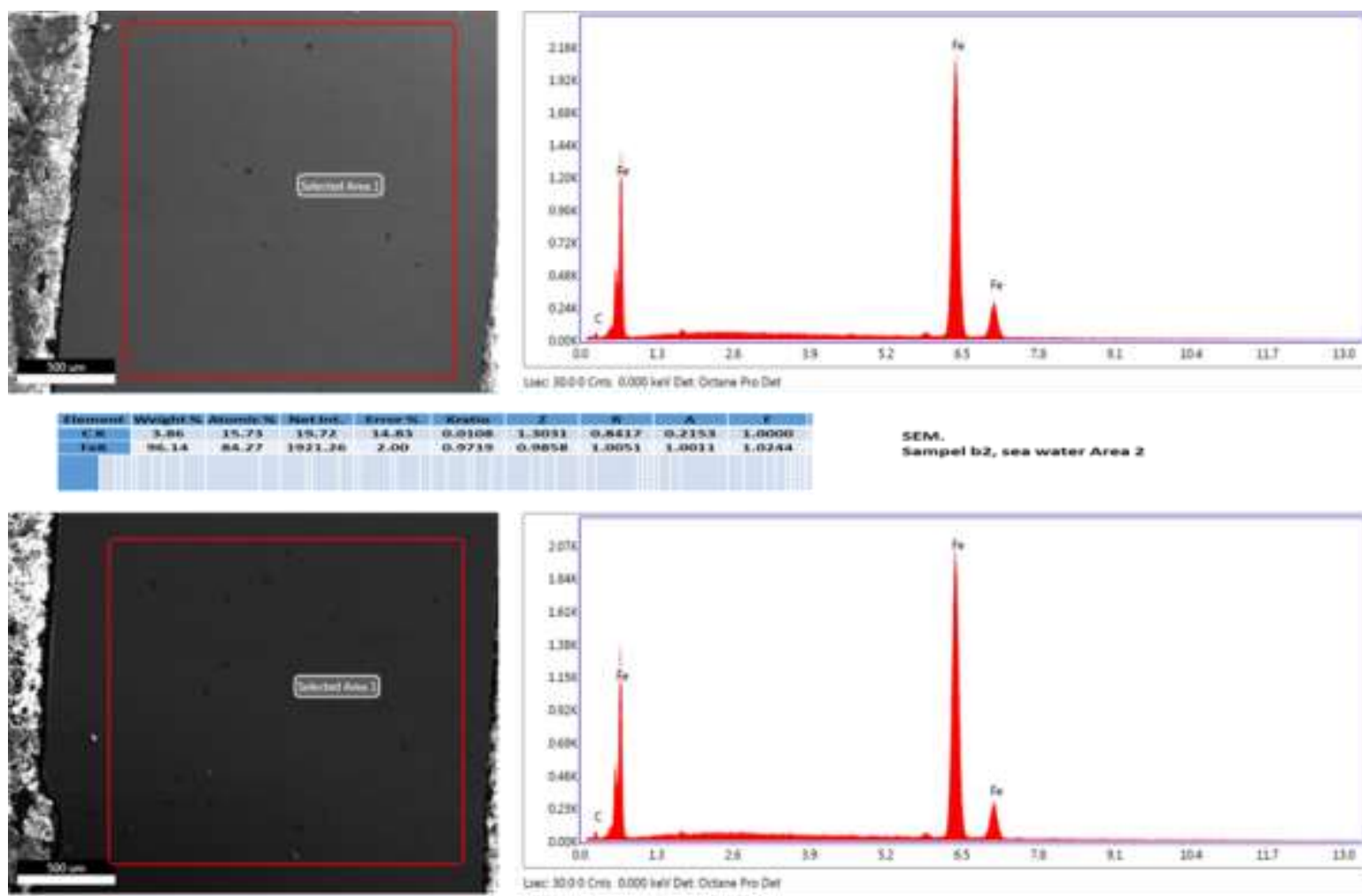

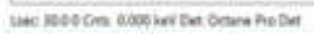
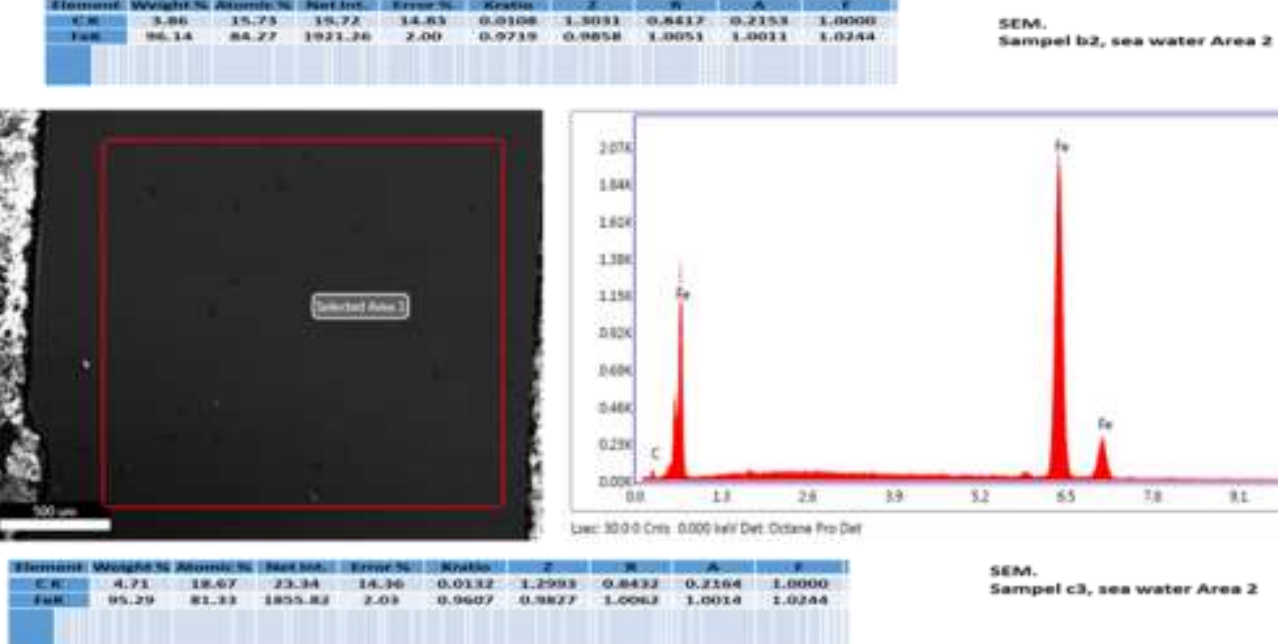

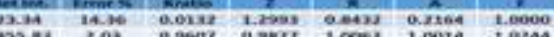

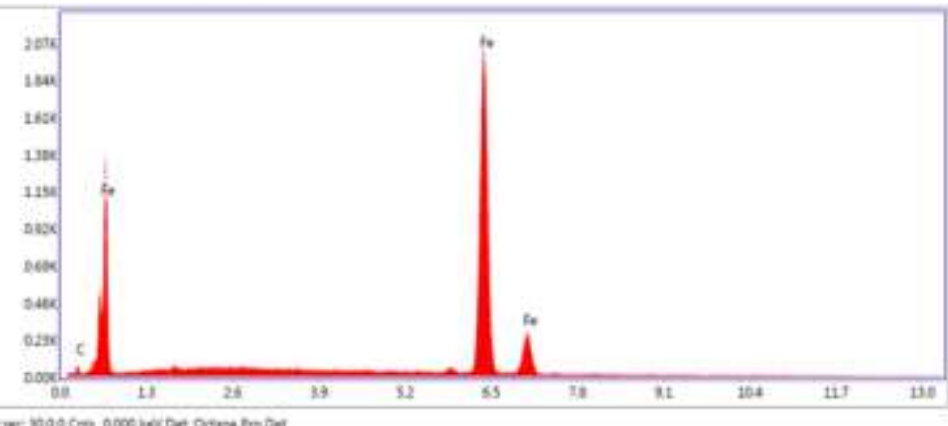

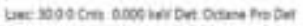

$\operatorname{sen}$.

Figure 10. Result SEM-EDS for b2 and c3 samples.

Table 4. percentage weight and percentage atoms for element $\mathrm{C}$ and element $\mathrm{Fe}$

\begin{tabular}{|c|c|c|c|c|}
\hline No. & $\begin{array}{l}\text { Weig } \\
\text { ht C } \\
(\%)\end{array}$ & $\begin{array}{c}\text { Atomi } \\
\text { c C } \\
(\%)\end{array}$ & $\begin{array}{l}\text { Weight } \\
\text { Fe (\%) }\end{array}$ & $\begin{array}{c}\text { Atomi } \\
\text { c Fe } \\
(\%)\end{array}$ \\
\hline 1 & 4.21 & 16.97 & 95.79 & 83.03 \\
\hline 2 & 4.23 & 17.05 & 95.77 & 83.95 \\
\hline 3 & 3.86 & 15.73 & 96.14 & 84.27 \\
\hline 4 & 4.71 & 18.67 & 95.29 & 81.33 \\
\hline vera & 4.252 & & & \\
\hline
\end{tabular}

The result of the SEM-EDS test as shown in Figure 9 for the B2 test sample that the $\mathrm{C}$ element has a weight of $4.21 \%$ and the atomic composition is $16.97 \%$, while $\mathrm{Fe}$ element has a weight of $95.79 \%$ and the atom composition is $83.03 \%$. And SEM-EDS test result for $\mathrm{C} 3$ sample that element $\mathrm{C}$ has $4.23 \%$ weight and atom composition $17,05 \%$, while element $\mathrm{Fe}$ has $95,77 \%$ weight and atom composition $83,95 \%$. Based on Figure 10 for the test sample B2 that element $\mathrm{C}$ has a weight of $3.86 \%$ and the atomic composition is $15.73 \%$, while Fe element has a weight of $96.14 \%$ and the atomic composition is $84.27 \%$. And the SEM-EDS test results for C3 test assays that element C has a weight of $4.71 \%$ and its atomic composition is $18.67 \%$, while Fe element has a

96 IEKSAKTA: Berkala IImiah Bidang MIPA 
weight of $95.29 \%$ and its atomic composition is $81.33 \%$. So the average composition for element $\mathrm{C}$ is that it weighs $4.2525 \%$, the atom is $17.105 \%$ and for element $\mathrm{Fe}$ is that a weighs $95.77475 \%$, the atom is $83.145 \%$.

Based on the data as in Table 1 and based on the graph as shown in FIG. 3 that the corrosion rate increases with the amount of deflection given to the test sample, and the table 3 of figure 4 corrosion rate increases with the magnitude of the strain $\sigma$ given to the test sample. And the test samples which are in the solution of $7900 \mathrm{ml}$ of sea water and $100 \mathrm{ml}$ of ammonia with loaded $\mathrm{CO} 2$ gas in saturated state and $\mathrm{H} 2 \mathrm{~S}$ gas every two days for 10 minutes then there is corrosion crack voltage (SCC) because CO2 gas, H2S gas and ammonia are source corrosive.

The corrosion events occur are the stress corrosion cracking transgranular and intergranular as shown in figure 6 , and based on the results of polarized microscopes as in figure 7 also occurred corrosion events. And percentage component of the chemical element that is dominant based on the results of the SEM-EDS test for sample b2 and sample c3 as shown in the table 4, which is either the percentage of the weight or percentage of the atom.

\section{Conclusion}

Synthesis of copper oxide on copper thin plate (thickness of 200-250 $\mu \mathrm{m}$ ) was successfully performed at temperature $380 \mathrm{oC}$ for 1 hour. The characterization results of DTA, SEM and XRD have provided information that during thermal oxidation formed $92.6 \% \mathrm{Cu}_{2} \mathrm{O}$ and $6.4 \% \mathrm{CuO}$ with $25 \mu \mathrm{m}$ thickness and maximum oxygen attack at 129 $\mu \mathrm{m}$ depth. Oxides formed on the oxidation process can be applied to visible light photovoltaic panels with continued research of physical properties and optical materials to obtain materials with appropriate photovoltaic functions.

\section{Acknowledgement}

1). I thank you for your help and enter to my fellow lecturers and technicians in the Department and Electrical Engineering, Department Faculty of Mathematics and Natural Sciences, University of Padjadjaran.

2). Acknowledgments that this research is funded from an Unpad Internal Grant ((HIU) with contract number 872 / UN6.3.1 / LT / 2017 and contract number

2385/UN6.D/KS/2018. .

\section{References}

[1] Nendi Suhendi-Sri Suryaningsih-Otong Nurhilal. (November 2014), "Study Stress Corrosion Cracking due to sweet gas $\left(\mathrm{H}_{2} \mathrm{~S}\right.$ and $\left.\mathrm{CO}_{2}\right)$ on Carbon Pipe", FMIPA Universitas Padjadjaran.

[2] Nendi Suhendi Syafei, Sri Suyaningsih, Otong Nurhilal, Febi Luthfiani. (Ed. Nov 2015), "Stress Analysis on API 5L GradeB Carbon Steel Pipes Against Corrosion Rate in $\mathrm{NaCl}$ and Acetic Acid Solutions". Indonesian Physics Journal No. 56 Vol. XIX ISSN 1410-2994.

[3] Nendi Suhendi Syafei-Zaida-Liu Kin Men (December 2016). "Voltage Crack Corrosion Study due to sweet gas (H2S and CO2) in the API 5L-X65 carbon fiber to the Corrosion Rate in Acetic Acid Solution and Analyzed by Ultrasonic Method", Electrical Engineering Study Program FMIPA Padjadjaran University. 
[4] Desy Nur Rochmah, Faried Latief, Tuti Susilawati, Norman Syakir, Fitrilawati; The Effect of Temperature on the Characteristics of Poly Corrosion Protection (TMSPMA) on the Surface of Carbon Steel, Proceedings of the National Seminar on Physics and its Application, 19 November 2016.

[5] Heri Jodi, Characterization of Corrosion of Steel SS-430 in the $\mathrm{NaCl}$ environment, Center for Nuclear Industrial Material Technology - BATAN, Puspiptek Serpong-Tangerang Selatan Region, (http://widyariset.pusbindiklat.lipi.go.id/index.php/ widyariset / article / ..., 28 February 2018).

[6] Nendi Suhendi Syafei - Darmawan Hidayat - Bernard Y Tumbelaka - Zaida - Liu Kin Men. (February 4, 2017), "Analysis of Corrosion Rate in API 5L-X65 Carbon Steel Pipe with Three-Point Loading Method on H2S Gas Environment CO2 Saturated Condition in Acetic Acid Solution", Proceedings of the National Seminar on Innovation and Application of Technology in Industry, ITN Malang, p. . D12.1-D12.5, ISSN 2085-4218.

[7] Nendi Suhendi Syafei, Darmawan Hidayat, Dessy Novita, Bernard Y Tumbelaka, Hardness Testing and Tensile Test to Determine the Hardening Coefficient $n$ An API Material 5L-X65, Proceedings of the Central Java \& DIY XXXI HFI Scientific Meeting, Yogyakarta March 182017 ISSN: 0853 -0823.

[8] Nendi Suhendi Syafei-Darmawan Hidayat-Bernard Y Tumbelaka-Muhammad taufik. (May 9, 2017), "Characteristics of API 5L-X65 Carbon Steel Pipe with Three-Point Imposition Method on $\mathrm{H} 2 \mathrm{~S}$ Gas Environment CO2 Saturated Condition in Acetic Acid Solution", Proceedings of the National Seminar on Energy and Technology (Synergy) Unisma Bekasi, p.33-39, ISSN: 2527-3108.

[9] Nendi Suhendi Syafei-Darmawan Hidayat-Bernard Y Tumbelaka-Liu Kin Men, Analysis of the corrosion phenomenon of API 5L-X65 carbon steel pipe plates in a solution of $250 \mathrm{ml}$ of acetic acid and 4750 aquades under conditions of CO2 and H2S gas saturated at room temperature, exact Vol. 18 N [10] Nendi Suhendi Syafei, -Liu Kin Men, Comparison of Voltage Crack Corrosion Studies from Sweet Gas (H2S and CO2) in API 5L-X65 Carbon Steel Pipes Against Corrosion Rate in Acetic-Ammonia Acid Solutions with Seawater and Analyzed Using Methods Ultrasonic, Unpad Research Research Grant (RFU-HIU 2107, Padjadjaran University).

[11] O. I. Zvirko, S. F. Savula, V. M. Tsependa, G. Gabetta, H. M. Nykyforchyn. (2016), "Steels' stress corrosion cracking of gas pipelines of different strength", 21st European Conference on Fracture, ECF21, 20-24 June 2016, Catania, Italy. Procedia Structural Integrity 2 509-516.

[12] Martin Monnota, Ricardo P. Nogueira, Virginie Roche, Grégory Berthomé, Eric Chauveau, Rafael Estevez, Marc Mantel (2017). "Sulfide stress corrosion study of a super martensitic stainless steel in $\mathrm{H} 2$ Sour environments: Metallic sulfides formation and hydrogen embrittlement", Applied Surface Science 394 132-141.

[13] Nendi Suhendi Syafei, Darmawan Hidayat, Bernard Y Tumbeleka, Liu Kin Men, Corrosion rate on API 5L-X65 carbon steel pipe with a three-point method of loading on acetic acid solution filled with $\mathrm{CO} 2$ and $\mathrm{H} 2 \mathrm{~S}$ gas in saturated state, RAPI XVI National Symposium - 2017 FT UMS Surakarta December 13, 2017, ISSN 1412-9612, p. 202-207.0.2, October 2017, pages 113-120, E-ISSN: 25497464, P-ISSN: 1411-3724.

98 IEKSAKTA: Berkala IImiah Bidang MIPA 
[14] Nendi Suhendi Syafei, Darmawan Hidayat, Bernard Y Tumbelaka, Liu Kin Men, Analysis of Strain Strain Corrosion Analysis on Fire Carbon Steel Pipes 5L-X65 in a Solution of $7900 \mathrm{ml}$ of Sea Water and $100 \mathrm{ml}$ of Ammonia with CO2 and H2S Gas in Saturated State, National Seminar on Innovation and Application of Technology in Industry 2018, ISSN 2085-4218 ITN Malang, February 3, 2018, p. 38-46).

[15] Nendi Suhendi Syafei-Darmawan Hidayat-Emilliano-Liu Kin Men, "Analysis Cracking Corrosion on Carbon Steel Pipes API 5LX65 in Solution 7700 ml Aquades, $250 \mathrm{ml}$ Acetic Acid and $50 \mathrm{ml}$ Ammonia with Gas CO2 and $\mathrm{H} 2 \mathrm{~S}$ in Saturation Condition", Eksakta vol 19 No.2 (2018), page 21-31;E-ISSN : 25497464, P-ISSN : 1411-3724, 30 oktober 2018 